\title{
The Psychological Condition Differences Between the Rural and Urban Poor Society
}

\author{
Puput Noviawatia $^{\mathrm{a}}$, Siti Nuzuliab ${ }^{\mathrm{b}}$ Marlina $^{\mathrm{c}}$, Anna Undarwatid \\ Psychology Department, Semarang State University \\ Semarang, Indonesia \\ Corresponding e-mail: ${ }^{\mathrm{a} p p t n o v i a w a t i @ g m a i l . c o m, ~}{ }^{\mathrm{b}}$ nuzuliaavianto@gmail.com, ${ }^{\mathrm{c}}$ marlinadisa@gmail.com, \\ dannaundar@gmail.com
}

\begin{abstract}
Poverty is a multidimensional problem which caused by various factors. In overcoming this problem, it is not limited to only giving materially but also it is important to understand the problem psychologically. This research is aimed to know the psychological differences between the rural and urban poor society. The study uses quantitative approach. The population characteristics are poor family (consists of father, mother and children between 9-12 years old), daily income less than 2 US dollars (WHO poverty criteria), live in municipality (for urban) and live in village town in a regency (for rural). The sample in this study is 300 samples (consist of fathers, mothers and children). Sampling technique is using quota sampling. This research measured attribution variables into dimensions of fatalistic, structuralistic and individualistic. The results of the research suggests that there are differences in three dimensions. There is no difference between fatalistic attribution of urban society and fatalistic attribution of rural society $(\mathrm{F}=0.487, \mathrm{p}=0.486)$. There is a very signficant difference between individualistic attribution of urban and rural society $(\mathrm{F}=9.54, \mathrm{p}=0.002)$. The rural sosiety has higher individualistic attribution than that of the urban society (mean comparison $=2.77<3.17$ ). There is no difference between structuralistic attribution of urban society and structuralistic attribution of rural society $(\mathrm{F}=3.45, \mathrm{p}=0.065)$.
\end{abstract}

Keywords: poverty, attribution

\section{INTRODUCTION}

Poverty is one of the major problems that occur across the nation, such as in Indonesia. Indonesia is a country that get ranked 4th in the world with a population of at most that amounted to 255993674 inhabitants. Therefore, the large number of people causing Indonesia has problems against poverty. Until now, the number of poor people in Indonesia can not be overcome well. This is evidenced by the percentage increase in the number of poverty from year to year. In April 2014 the number of poor people in Indonesia was 11.7 percent. In September 2014 the number of poor people reached 27.73 million people or about $10.96 \%$ of the total population of Indonesia. In March 2015, there was a $10 \%$ increase to 28.85 million poor people in Indonesia.

Actually, the government has made various efforts to overcome the problem of poverty. However, the allocation of funds amounted to 54.23 trillion in 2013, and 56 trillion rupiah in 2014, as well as programs that have been implemented by the government from the Rice Poor Program, Family Hope Program, Poor Student Support Program, PNPM independent, Direct Community assistance, and the Program's Business Credit, have not produced significant results.

The poverty condition can occur between the rural and urban poor society. Both of these groups allegedly different characteristics due to differences in demographic and socio-cultural location. In this case, poverty is not only seen from the perspective of economics, but also very necessary psychological understanding. Meanwhile, research in Indonesia on poverty has been using economic point of view (Markum, 2008). People who come from bad economic conditions will feel unhappy and even have serious mental disorders such as depression, schizophrenia, and personality disorders (Dohrenwend, 1971; Warheit, Holzer \& Schwab, 1973, in Markum, 2009). Unfortunately, in Indonesia, the mental health conditions of the poor have not been paid much attention (Markum, 2009).

The example that poverty alleviation can not only be viewed from the eyes of the economy is the case of poverty that occurred in India. Indian society believes poverty is more due to fate, so whatever intervention the worldview affects community behavior that ultimately leads to failure of intervention (Heider, 1958; Harvey, 1984, in Wollie, 2009). Research conducted by Lever (2000) reveals how difficult it is to change the way people in the poverty chain become more optimistic. Lever (2000) describes mothers who are in a state of poverty will lower the values of "poor people" in their children. Mothers will lower low self-esteem, low achievement motivation, and self-efficacy (low selfesteem). So concluded, not only economic conditions are poor, but psychologically children born from poor families will also have "psychologically poor"

Therefore, understanding the psychological variables that are considered important in determining the success of poverty alleviation 
programs. Variables that need to be understood one of them is the attribution factor of poverty (Feagin, 1972; Wollie, 2009). The results of this study indicate that mapping the psychological attributes of the poor is important for predicting attitudes and behaviors and influencing one's performance in the future (Taylor, et al., 1997).

Furthermore, in order to understand the poor more comprehensively, this research divides the poor into two groups, the rural poor and the urban poor. Both of these groups allegedly different characteristics due to differences in demographic and socio-cultural location.

\section{THEORETICAL BASES}

\subsection{Poverty}

The concept of poverty is something very complex because poverty is a multidimensional phenomenon. World Bank in 2001 defined poverty as lack of material, weak social relations, insecurity and vulnerability, lack of confidence, and helplessness.

Conceptually poverty can be viewed in many ways. First in terms of subsystems, where the income and effort someone is just barely to eat alone, or even not enough for it. Second, the aspect of inequality emphasizes the relative position of each class according to its income to the position of the other group. Third, in terms of external reflects the social consequences of poverty on the people around him, which is how the protracted poverty resulting social impact is endless (Soerjani, 1987).

Based on the socio-psychological approach, poverty refers to the lack of networks and supportive social structures in obtaining opportunities in improving productivity. In addition, there are factors that hinder someone in exploiting the opportunities that exist in the community. Factor referred to, either because of internal factors that come from within a person, and / or external factors such as bureaucracy, the provisions in force in society and or government regulations. Such socio-psychological poverty is often termed structural poverty (Suradi, 2011: 225).

Furthermore, Zastrow (2008) is due to poverty, which are often leads to despair, low self esteem, and stunted growth - including physical, social, emotional, and intellectual growth. Poverty hurts most when it leads to a view of the self as inferior or second class

\subsection{Causal Attribution}

Psychological attributes is a theoretical construct that there are hypothetical and are drafted in order to describe the spiritual dimension of the individual (Anwar, 2005). In this psychological measurement, psychological attributes play a role in describing the psychological dimensions that exist in the human to the condition of poverty that occurred.

Attribution is a theory that discusses the efforts made to understand the causes of our behavior and others. Researchers [2] have mapped the attribution of internal and external causes of poverty in three dimensions. These three dimensions are the individualistic dimension of viewing poverty as a result of the individual's disposition factor, the fatalistic dimension, that is to regard poverty as the result of fate or misfortune and the structural dimension of poverty as a result of society. The same is revealed by Bullock (2006) who says that the three dimensions of poverty are a causal attribution of poverty.

\section{METHODS}

\subsection{Participants}

The population in this study is all the poor society who live in the urban and rural of Semarang. Characteristics of population are: poor families (consist of father, mother and children aged between 9-12 years), earning less than 2 US dollars, living in municipalities and living in rural towns within a district (for the village). The sample in this study will be taken over 300 samples (consisting of father, mother and child). The sampling technique uses quota sampling.

\subsection{Research Design}

This research uses quantitative research approach. By using the quantitative method will be obtained significance of group differences or significance of relationships among variables studied (Azwar, 2011). The research design used in this research are descriptive, correlational and comparative.

\subsection{Measures}

The data collection tool used in this study is the psychological scale. The psychological scale used is the nine psychological scales of causality causal scale of poverty, value scale, self-esteem scale, selfefficacy scale, achievement motivation scale, coping strategy scale, personality scale, depression scale and subjective well-being scale.

The stimulus is a question or statement that does not directly reveal the attributes to be measured, but reveals the behavioral indicators of the attributes in question. Due to the psychological attributes expressed indirectly through behavioral indicators whereas the behavioral indicators are translated in the form of aitem-aitem. Thus the psychological scale always contains many items. 
The subject's response is not classified as an answer Strongly Agree, Agree, Disagree and Strongly Disagree. All answers are acceptable as long as they are provided honestly and earnestly. Only, different answers will be interpreted differently.

\subsection{Data Analysis}

This research uses factor analysis to know the validity of construct research instrument. Meanwhile, instrument reliability was measured using cronbach alpha reliability technique with the help of SPSS.

Data analysis techniques in this study using descriptive data analysis techniques, comparative analysis techniques anava, and correlational correlation analysis techniques product moment.

\section{RESULTS AND DISCUSSION}

\subsection{Descriptive Statistics of Attribution Variables}

The following table 1. Shows thst the description of each attribution. It appears that attribution to the fatalistic dimension is higher than the structuralistic attribution and individualistic attribution. This means that most research subjects consider the poverty faced by the fate of God. Furthermore, poverty is caused by a government that is less responsible, and the last cause of poverty is a factor of lack of skill and individual ability.

Table 1. Descriptive Statistics of Attribution Variables

\begin{tabular}{|c|c|c|c|c|c|}
\hline & $\mathrm{N}$ & Min & Max & Mean & $\begin{array}{c}\text { Std. } \\
\text { Deviation }\end{array}$ \\
\hline Fatalistic & 200 & 2.00 & 8.00 & 3.3100 & 1.07689 \\
\hline $\begin{array}{c}\text { Individualis } \\
\text { tic }\end{array}$ & 200 & 2.00 & 6.00 & 2.9700 & .97150 \\
\hline $\begin{array}{l}\text { Structuralis } \\
\text { tic }\end{array}$ & 200 & 2.00 & 7.00 & 3.2550 & 1.11183 \\
\hline $\begin{array}{c}\text { Valid N } \\
\text { (listwise) }\end{array}$ & 200 & & & & \\
\hline
\end{tabular}

\subsection{Hypothesis Test Result of Attribution Variables}

Table 2 shows that :

- There is no difference between fatalistic attribution in urban society and fatalistic attribution in rural society $(\mathrm{F}=0.487, \mathrm{p}=0.486)$.

- There is a very significant difference between the individualistic attribution of urban society and rural society $(F=9.54, p=0.002)$. Rural society is higher in individualistic attribution than urban society (mean comparison $=2.77<3.17$ ).
- There is no difference between structuralistic attribution in urban society and structuralistic society in rural society $(F=3.45, p=0.065)$.

- There is a very significant difference between fatalistic attribution between children and parents. $(F=28.106, p=0.000)$. Parents had higher fatalistic attributions than children (mean comparison $=3.69>2.93$ ) .

- There is a very significant difference between individualistic attribution between children and parents. $(\mathrm{F}=11,543, \mathrm{p}=0.001)$. Parents are higher in individualistic attribution than children (mean comparison $=3.19>2.75$ ).

- There is no difference between structuralistic attribution in children and parents $(\mathrm{F}=1.481, \mathrm{p}=$ $0.225)$.

- There is no difference of fatalistic attribution in urban and rural society, either in the elderly or children $(\mathrm{F}=0.00, \mathrm{p}=1.00)$.

- There is a significant difference of individualistic attribution between urban and rural society, in the parents and children $(\mathrm{F}=6.893, \mathrm{p}=0.009)$. Villagers are higher than urban society (Comparison of mean $=3.36>3.26$ ). Parents are higher than children (Mean $=3.69>2.93$ ). Village parents are higher than urban parents $($ Mean $=3.74>3.64)$. The village child is higher than the urban child (Mean 3.166>2.88).

- There is no difference of structuralist attribution in urban and rural society, either in the parents or children $(\mathrm{F}=9.23, \mathrm{p}=0.338)$.

\begin{tabular}{|c|c|c|c|c|c|c|}
\hline Source & Dependent Variable & $\begin{array}{c}\text { Type III Sum of } \\
\text { Squares }\end{array}$ & $d f$ & Mean Squars & $\mathrm{F}$ & Sig. \\
\hline \multirow{4}{*}{ Lokasi } & Fatalistik & 500 & 1 & .500 & .487 & .486 \\
\hline & Individualistik & 8.000 & 1 & 8.000 & 9.540 & .002 \\
\hline & Stukturalistik & 4.205 & 1 & 4.205 & 3.450 & .065 \\
\hline & Fatalistik & 28.880 & 1 & 28.880 & 28.106 & .000 \\
\hline \multirow[t]{3}{*}{ Statuskeluarga } & Individualistik & 9.680 & 1 & 9.680 & 11.543 & .00 \\
\hline & Stukturalistik & 1.805 & 1 & 1.805 & 1.481 & .225 \\
\hline & Fatalistik & .000 & 1 & .000 & .000 & 1.000 \\
\hline \multirow[t]{2}{*}{ Lokasi ' Statuskeluarga } & Individualistik & 5.780 & 1 & 5.780 & 6.893 & .009 \\
\hline & Stukturalistik & 1.125 & 1 & 1.125 & .923 & .338 \\
\hline
\end{tabular}

\subsection{Discussion}

Fatalistic attribution is more dominant than structuralistic attribution and individualistic attribution. The fatalistic attribution in this study is more dominant than other attributions. That is, people believe that the poor condition experienced is caused by the fate of God. However, no differences in fatalistic attribution were found between urban and rural society. Fatalistic attributions in parents and children are found to be different. Parents have a higher fatalistic attribution than children. This means that the value adopted by parents is not adopted by the child. However, if residence is also taken into consideration, then the fatalistic attribution between parents and children is no different. 
A further finding is that there is a very significant difference between the individualistic attribution of urban society and rural society. Rural society is higher in individualistic attribution than in urban society. This means that villagers assume that their skills and knowledge play a greater role in contributing to the current poor situation than the urban community. Individualistic attribution is found to be higher in parent than in child. That is, the belief of parents who say that poverty is due to lack of skills and knowledge does not decrease in children. While there is no distinction between structuralistic attribution in society, the values that parents believe that poverty is one of them is that lack of support from the government is also believed and believed by the child.

\section{CONCLUSION}

Based on the results of research on differences in causal attribution between urban and rural poor, that is, from the three dimensions of causal attribution the fatalistic dimension is more dominant than the individualistic and structuralistic dimensions. But there is no difference in the fatalistic dimensions of urban and rural communities. In the structuralistic dimension there is no difference between structuralistic attribution in urban communities and structuralistic attribution in rural communities. Differences are gained on the Individualistic dimension.

\section{REFERENCES}

[1] Azwar. S. (2004). Metode Penelitian, Pustaka Pelajar, Yogyakarta.

[2] Feagin, J. (1972). Poverty We Still Believe that God Helps Who Help Themselves. Psychology Today, 6, 01-129.

[3] Markum. (2009). Pengentasan Kemiskinan dan Pendekatan Psikologi Sosial. Psikobuana, 1-12.

[4] Soerjani, Moh. (1987). Sumber Daya Alam dan Kependudukan Dalam Pembangunan. Jakarta: Universitas Indonesia.

[5] Suradi. (2011). Peranan Sektor Informal dalam Penanggulangan Kemiskinan. Jurnal Informasi.

[6] Taylor, Shelley E., Peplau, Letitia Anne., dan Sears, David O. (1997). Social Psychology. New Jersey: Simon \& Schuster A Viacom Company.

[7] Ellis, G.F.R. (1984). The Dimensions of Poverty. Social Indicator Research 15. D. Reidel Publishing Company.

[8] Harper. J. David. (2001). Poverty and Discourse. Poverty \& Psychology: From Global Perspective to Local Practice. New York: Kluwer-Plenum

[9] Lever P. J, Lanzagorta, Pinol. \& Uralde, J.H. (2004). Poverty, Psychological Resources and Subjective Well-Being. Social Indicator Research, 73, 375-408. 